\title{
Infeksi dan Pola Kepekaan Stenotrophomonas maltophilia di ICU RS X
}

\author{
Nicolas Layanto, Ade Dharmawan \\ Departemen Mikrobiologi, Fakultas Kedokteran dan Ilmu Kesehatan, Universitas Kristen Krida Wacana, \\ Jakarta, Indonesia \\ Alamat Korespondensi: nicolas.layanto@ukrida.ac.id
}

\begin{abstract}
Abstrak
Infeksi Stenotrophomonas maltophilia dapat terjadi di berbagai organ, namun bakteri ini paling sering ditemukan pada paru. Angka kematian pada pasien dengan infeksi S. maltophilia cukup tinggi, tetapi berkaitan erat dengan kondisi pasien. Bakteri ini memiliki kekebalan intrinsik yang luas, antibiotik yang dapat digunakan lebih terbatas, serta diperlukan pengendalian infeksi yang baik dalam penanganannya. Penelitian ini bertujuan untuk mendapatkan data prevalensi S. maltophilia di ICU RS X dan pola kepekaannya. Seluruh sampel yang berasal dari ICU diambil dan jika ditemukan S. maltophilia, maka akan dimasukkan ke dalam studi. Ditemukan seluruh sampel dengan pertumbuhan S. maltophilia berasal dari paru, dengan sebagian besar disertai Pneumonia COVID-19. Prevalensi infeksi paru S. maltophilia 25,31\%, dengan mortalitas mencapai 52,94\%. Ditemukan kepekaan cotrimoxazole $95 \%$ dan levofloxacin 83,33\%. Cotrimoxazole dan levofloxacin masih ideal untuk menangani infeksi S. maltophilia dengan tetap menerapkan pencegahan dan pengendalian infeksi yang baik.
\end{abstract}

Kata Kunci: cotrimoxazole, ICU, levofloxacin, Stenotrophomonas maltophilia

\section{Infection and Antibiotic Susceptibility of Stenotrophomonas maltophilia in Hospital X ICU}

\begin{abstract}
Stenotrophomonas maltophilia infection can spread to various organs, with lung is the most common site of positive S. maltophilia culture. High mortality rate from patient with S. maltophilia infection is also related to the patient condition. Related to wide intrinsic resistance, less option of antibiotic can be used, and a good infection control must be implemented. The aim of this study is to obtain prevalence of S. maltophilia in ICU and the antibiotic sensitivity pattern. All samples from ICU of X Hospital were tested, and included in this study if S. maltophilia were isolated. All positive S. maltophilia cultures were isolated from lung and mostly diagnosed with COVID-19 pneumonia. S. maltophilia lung infection prevalence is $25.31 \%$, mortality rate $52.94 \%$. Cotrimoxazole sensitivity is $95 \%$, and levofloxacin is $83.33 \%$. Both antibiotic are still useful for S. maltophilia infection, along with good infection control.
\end{abstract}

Keywords: cotrimoxazole, ICU, levofloxacin, Stenotrophomonas maltophilia

How to Cite :

Layanto N., Dharmawan A. Infeksi dan Pola Kepekaan Stenotrophomonas maltophilia di ICU RS X. J Kdokt Meditek. 28(1), 24-29.

Available from: http://ejournal.ukrida.ac.id/ojs/index.php/Meditek/article/view/2310/version/2300 DOI:

https://doi.org/10.36452/jkdoktmeditek.v28i1.2310 


\section{Pendahuluan}

Stenotrophomonas maltophilia adalah bakteri batang gram negatif, yang memiliki flagel dan bersifat aerob. Bakteri ini umumnya berada di lingkungan berair atau lembab termasuk pada sumber air minum di rumah sakit. Bakteri ini mudah tumbuh di medium kultur yang rutin digunakan karena tidak memerlukan medium kultur yang khusus. Sebelum digolongkan terpisah, bakteri ini sering diidentifikasi sebagai bagian dari Pseudomonas dan pernah diberi nama Pseudomonas maltophilia dan Xanthomonas maltophilia. ${ }^{1}$

Bakteri ini memiliki resistensi intrinsik terhadap berbagai antibiotik seperti antibiotik golongan betalaktam, fluoroquinolone, aminoglikosida, erithromisin, kloramfenikol, dan tetrasiklin. Bakteri ini juga tahan terhadap beberapa jenis desinfektan dan silver. Desinfektan yang dimaksud tidak hanya terbatas pada desinfektan lingkungan, namun hingga berbagai jenis cairan untuk menjaga kebersihan lensa kontak. $^{2}$ Hal ini disebabkan oleh banyaknya tipe efflux pump yang dimiliki oleh $S$. maltophilia. Bakteri ini memiliki pili dan fimbriae yang memudahkan untuk adhesi serta pembentukan biofilm. Gen pengode efflux pump, pili, dan fimbriae tersebut tersebar di integron, transposon, dan plasmid. Pada S. maltophilia yang ditemukan di rumah sakit, juga ditemukan betalaktamase, enzim untuk mengganggu kerja aminoglikosida, serta permeabilitas outer membrane yang menurun. Banyaknya resistensi intrinsik membuat pilihan antibiotik menjadi semakin terbatas. ${ }^{1,3}$

Studi yang dilakukan oleh Nseir dkk. melaporkan prevalensi infeksi $S$. maltophilia sebesar $2 \%$, begitu juga studi yang dilakukan di Bali, Indonesia oleh Budayanti dkk. didapatkan prevalensi $S$. maltophilia sebesar $1 \% .{ }^{4,5}$ Prevalensi $S$. maltophilia di unit perawatan intensif tidak banyak, namun dapat meningkatkan angka mortalitas yang signifikan. Sebuah studi yang dilakukan oleh Guerci dkk. didapatkan angka mortalitas $49 \%$ pada pasien di Perancis yang dirawat di ruang unit intensif dengan diagnosis Hospital Acquired Pneumonia (HAP). ${ }^{6}$

Infeksi dapat terjadi pada paru dan umumnya diawali dengan kolonisasi. Infeksi pada paru merupakan infeksi yang paling sering terjadi dibanding infeksi yang melibatkan pembuluh darah, yang umumnya berasal dari selang kateter intravaskular. ${ }^{1,3}$ Infeksi $S$. maltophilia lebih sering terkait dengan perawatan di rumah sakit dan terkait dengan riwayat penggunaan antibiotik sistemik spektrum luas. ${ }^{1,7-12}$ Bakteri ini juga dapat ditemukan di berbagai tempat di rumah sakit. ${ }^{1,7,10,13}$ Hal ini menyebabkan, S. maltophilia dapat menyebabkan outbreak di ruang perawatan di rumah sakit. Penelitian ini ditujukan untuk melihat prevalensi infeksi $S$. maltophilia di ICU rumah sakit serta melihat kepekaan antibiotik cotrimoxazole dan levofloxacin sebagai antibiotik pilihan utama.

\section{Metodologi}

Penelitian ini bersifat deskriptif, data diambil dari data sekunder yaitu melalui data yang tersimpan secara elektronik di laboratorium Mikrobiologi RS X pada rentang waktu 1 Januari 2020 hingga 30 Agustus 2021. Kriteria inklusi meliputi semua sampel kultur dari ICU berupa darah, sputum, urin, dan pus/jaringan yang didapatkan hasil kultur Stenotropomonas maltophlia diambil. Seluruh isolat dilakukan uji kepekaan terhadap cotrimoxazole (menggunakan Vitek2) dan uji terhadap levofloxacin menggunakan difusi cakram sesuai panduan CLSI (Clinical and Laboratory Standards Institute) yaitu uji kepekaan menggunakan agar Muller-Hinton. Koloni Stenotropomonas maltophlia dibuat kekeruhan 0,5 McFarland sebelum ditanam di medium agar tersebut, dan diletakkan cakram levofloxacin $5 \mu \mathrm{g}$. Interpretasi kepekaan dilakukan sesuai panduan CLSI 2020, Cotrimoxazole dianggap sensitif jika MIC (Minimum Inhibitory Concentration) $\leq 2 \mu \mathrm{g} / \mathrm{ml}$, sedangkan levofloxacin dianggap sensitif jika diameter zona hambat $\geq 17$ $\mathrm{mm}^{14}$

\section{Hasil}

Berdasarkan hasil kultur dari spesimen saluran napas bawah, didapatkan 79 pertumbuhan isolat baik bakteri gram negatif, gram positif, dan jamur. Persentase isolat S.maltophlia dari saluran napas pada penelitian ini adalah 25,31\%. Stenotrophomonas maltophilia dari hasil kultur pertama kali ditemukan di ICU RS pada bulan Desember 2020 atau hampir 1 tahun sejak pertama RS beroperasi. Sejak awal ditemukan, setiap bulan selalu ditemukan bakteri ini kecuali pada bulan Mei 2021 (Tabel 1). Berdasarkan hasil kultur ditemukan 20 isolat Stenotrophomonas maltophilia dari 17 pasien. Terdapat 2 pasien yang ditemukan pertumbuhan S. maltophilia lebih dari 1 kali dalam rentang waktu kurang dari 30 hari. Pasien pertama (dirawat sejak Februari hingga Maret 2021) tumbuh S. maltophilia sebanyak 2 kali dengan pola 
kepekaan yang sama sehingga 1 isolat dikeluarkan dari penelitian sedangkan pada pasien kedua (April 2021), tumbuh $S$. maltophilia dengan pola kepekaan yang berbeda-beda sehingga seluruhnya diambil untuk penelitian ini.

Pasien yang ditemukan isolat S. maltophilia, lama perawatan berkisar antara 12-175 hari. Tingkat mortalitas pada pasien dengan yang ditemukan S. maltophilia pada spesimen sputum di penelitian ini adalah 52,94\%. Ditemukan 17 pasien dengan kultur positif S.maltophilia, 16 diantaranya terdiagnosis Pneumonia COVID-19 dan memerlukan perawatan di ICU. Berdasarkan tanggal masuk perawatan dan tanggal keluar perawatan, setiap pasien tersebut selalu dirawat saat ada pasien yang sedang/ pernah ditemukan isolat S. maltophilia.

Seluruh isolat dilakukan uji kepekaan terhadap cotrimoxazole dan levofloxacin kecuali 1 isolat akibat ketidaksediaan cakram levofloxacin. Tidak ditemukan Stenotrophomonas maltophlia dari sampel lain selain sputum/saluran napas bawah. Hasil uji kepekaan disajikan pada tabel.3.

Tabel 1. Sebaran Waktu Ditemukan Isolat S.maltophilia

\begin{tabular}{lccccccccc}
\hline & $\begin{array}{c}\text { 2020 } \\
\text { Desember }\end{array}$ & Januari & Februari & Maret & April & Mei & Juni & Juli & Agustus \\
\hline $\begin{array}{l}\text { Jumlah isolat } \\
\begin{array}{l}\text { S.maltophilia } \\
\text { Jumlah pasien yang }\end{array}\end{array}$ & 1 & 4 & 2 & 1 & 4 & 0 & 2 & 4 & 2 \\
$\begin{array}{l}\text { ditemukan } S . \\
\text { maltophilia }\end{array}$ & 1 & 4 & 2 & 1 & 2 & 0 & 2 & 4 & 2 \\
\hline
\end{tabular}

Tabel 2. Hasil Akhir Perawatan dan Lama Perawatan Pasien

\begin{tabular}{|c|c|c|c|c|c|c|}
\hline No. & Pasien & $\begin{array}{c}\text { Lama } \\
\text { Perawatan } \\
\text { (hari) }\end{array}$ & $\begin{array}{l}\text { Tgl Masuk } \\
\text { Rawat }\end{array}$ & $\begin{array}{l}\text { Tgl Keluar } \\
\text { Rawat }\end{array}$ & Hasil akhir & $\begin{array}{l}\text { Diagnosa } \\
\text { Covid19 }\end{array}$ \\
\hline 1 & Pasien 1 & 57 & $31 / 10 / 20$ & $16 / 01 / 21$ & Pulang & $\mathrm{Ya}$ \\
\hline 2 & Pasien 2 & 175 & $26 / 11 / 20$ & $08 / 01 / 21$ & Meninggal & $\mathrm{Ya}$ \\
\hline 3 & Pasien 3 & 66 & $20 / 12 / 20$ & $25 / 02 / 21$ & Pulang & $\mathrm{Ya}$ \\
\hline 4 & Pasien 4 & 18 & $13 / 01 / 21$ & $01 / 02 / 21$ & Pulang & Tidak \\
\hline 5 & Pasien 5 & 29 & $17 / 02 / 21$ & $18 / 02 / 21$ & Pulang & $\mathrm{Ya}$ \\
\hline 6 & Pasien 6 & 38 & $28 / 01 / 21$ & $08 / 03 / 21$ & Pulang & $\mathrm{Ya}$ \\
\hline 7 & Pasien 7 & 35 & $07 / 02 / 21$ & $06 / 03 / 21$ & Meninggal & $\mathrm{Ya}$ \\
\hline 8 & Pasien 8 & 87 & $07 / 03 / 21$ & $03 / 06 / 21$ & Meninggal & $\mathrm{Ya}$ \\
\hline 9 & Pasien 9 & 30 & $02 / 04 / 21$ & $01 / 05 / 21$ & Meninggal & $\mathrm{Ya}$ \\
\hline 10 & Pasien 10 & 12 & $30 / 05 / 21$ & $11 / 06 / 21$ & Meninggal & $\mathrm{Ya}$ \\
\hline 11 & Pasien 11 & 14 & $17 / 06 / 21$ & $01 / 07 / 21$ & Meninggal & $\mathrm{Ya}$ \\
\hline 12 & Pasien 12 & 63 & $07 / 06 / 21$ & $10 / 08 / 21$ & Pulang & $\mathrm{Ya}$ \\
\hline 13 & Pasien 13 & 19 & $01 / 07 / 21$ & $20 / 07 / 21$ & Meninggal & $\mathrm{Ya}$ \\
\hline 14 & Pasien 14 & 37 & $09 / 07 / 21$ & $15 / 08 / 21$ & Meninggal & $\mathrm{Ya}$ \\
\hline 15 & Pasien 15 & 10 & $12 / 07 / 21$ & $25 / 07 / 21$ & Meninggal & $\mathrm{Ya}$ \\
\hline 16 & Pasien 16 & 12 & $31 / 07 / 21$ & $13 / 08 / 21$ & Pulang & $\mathrm{Ya}$ \\
\hline 17 & Pasien 17 & 49 & $04 / 07 / 21$ & $26 / 08 / 21$ & Pulang & $\mathrm{Ya}$ \\
\hline
\end{tabular}

Tabel 3. Pola Kepekaan Stenotrophomonas maltophilia

\begin{tabular}{lllll}
\hline Isolat & $\begin{array}{l}\text { Uji Kepekaan } \\
\text { Antibiotik }\end{array}$ & Jumlah Tes & Jumlah Sensitif & Persentase Sensitif \\
\hline \multirow{2}{*}{ S. maltophilia } & Levofloxacin & 18 & 15 & $83,33 \%$ \\
& Cotrimoxazole & 20 & 19 & $95 \%$ \\
\hline
\end{tabular}




\section{Pembahasan}

Berdasarkan hasil yang didapat pada penelitian ini, ditemukan bahwa S.maltohilia paling sering menyebabkan infeksi pada paru, di mana seluruh isolat didapatkan dari spesimen saluran napas bawah, sesuai dari teori serta hasil studi Joanna (2012). ${ }^{1,12}$ Hasil yang sama juga tampak pada penelitian oleh Guoat dkk. (2013) di ICU, di mana selama periode penelitian mereka, $74 \%$ isolat S.maltophilia berasal dari spesimen saluran napas. ${ }^{7}$ Penelitian di sebuah ICU di Perancis menemukan bahwa $86,61 \%$ isolat S.maltophilia didapatkan dari spesimen saluran napas bawah. ${ }^{6}$ Studi di negara Eropa lain yaitu Yunani oleh Samonis (2012), juga menyatakan bahwa S.maltophilia ditemukan terbanyak pada spesimen paru yaitu $54,4 \%$. Penelitin tersebut dilakukan tidak terbatas di unit ICU saja. ${ }^{15}$ Terdapat penelitian serupa di Mataram, Indonesia oleh Hagni (2016) yang mengumpulkan spesimen tidak terbatas pada unit ICU saja. Didapatkan 12 isolat S.maltophilia selama Juni 2014-September 2015 dengan dominan berasal dari pasien pneumonia. ${ }^{16}$

Didapatkan hasil kultur S.maltophilia sejak Desember 2020 minimal dari 1 pasien kecuali pada bulan Mei. Tidak dapat dipastikan apakah strain yang menginfeksi pasien ini berasal dari strain yang sama karena tidak dilakukan studi molekuler dan antibiotik yang dapat diuji untuk S.maltophlia pada studi ini sangat terbatas sehingga pola resistensi yang didapatkan tidak dapat digunakan sebagai pembanding dari masing-masing isolat, namun terdapat kemungkinan bahwa bakteri ini berasal dari strain yang sama karena bakteri terutama jenis strain tertentu seperti strain dari lineage Sm6 ini dapat bertahan di lingkungan termasuk pada alat-alat medis yang digunakan dan juga tahan terhadap beberapa desinfektan. ${ }^{10,13}$ Studi lain juga menunjukkan bahwa S.maltophilia dapat ditemukan pada berbagai perlengkapan yang terkait dengan perawatan pasien serta di lingkungan sekitar yang tidak terkait dengan pelayanan medis. ${ }^{12}$ Tidak dilakukan swab pada lingkungan untuk membuktikan adanya $S$. maltophilia di lingkungan atau alat medis seperti yang dilakukan pada studi oleh Gideskog dkk. (2020) sehingga hipotesis ini sulit dipastikan. ${ }^{10}$ Berdasarkan data yang diperoleh, seluruh pasien dirawat di ICU dengan ruangan yang berdampingan, semua pasien menggunakan ventilator, dan berdasarkan tanggal masuk perawatan dan tanggal keluar, setiap pasien ini selalu masuk saat ada pasien dengan riwayat ditemukan S. maltophilia. Tidak pernah dilakukan kultur ulang sebagai bukti tidak lagi terdapat infeksi atau kolonisasi S. maltophilia setelah pemberian terapi. Terdapat 2 pasien yang didapatkan pertumbuhan S. maltophilia sebanyak 2 dan 3 sampel, dengan hasil akhir berturut-turut adalah sembuh dan meninggal. Sama seperti laporan kasus oleh Pek dkk (2021) di mana ditemukan kultur saluran napas bawah $S$. maltophilia pada pasien Pneumonia COVID-19 dengan pasien tersebut meninggal. Pada laporan kasus tersebut juga terdapat bukti bakteremia oleh bakteri yang sama. Hingga akhir perawatan, tetap ditemukan kolonisasi S. maltophilia. ${ }^{17}$

Lama perawatan pada pasien yang dilakukan selama studi ini berkisar antara 12-175 hari (ratarata 44,7 hari) dengan tingkat mortalitas pasien adalah 52,94\%. Studi ini memperlihatkan bahwa infeksi S.maltophilia ditemukan pada paru dan 94,11\% dari pasien ini terdiagnosis Pneumonia COVID-19 serta memerlukan perawatan di ICU (memerlukan alat bantu napas). Studi yang dilakukan Guerci dkk. (2019) juga mendapatkan angka mortalitas pada kasus HAP akibat $S$. maltophilia mencapai $49,7 \%$, dengan mortalitas yang secara langsung berhubungan dengan $S$. maltophilia mencapat $24,3 \%$, walaupun tercantum bahwa sulit menentukan bahwa angka kematian tersebut secara langsung akibat S. maltophilia ${ }^{6}$ Studi yang dipublikasi oleh Sadar (2007) juga mengemukakan bahwa angka kematian pada infeksi paru pada pasien kanker dapat mencapai lebih dari 50\%. ${ }^{18}$ Penelitian lain mengenai mortalitas pasien terinfeksi $S$. maltophilia di Thailand, didapatkan angka mortalitas mencapai $54 \%$, dengan $46 \%$ dari seluruh pasien yang diteliti sudah dalam kondisi sakit kritis saat masuk ke rumah sakit. ${ }^{19} \mathrm{Hal}$ ini serupa dengan penelitian ini di mana pada kasus kematian yang ditemukan, terbukti terdapat infeksi SARS-CoV2 yang dibuktikan dengan hasil qRT-PCR. Pada penelitian ini tidak melihat hasil kultur darah yang diambil bersamaan dengan sampel dari paru untuk membuktikan bakteremia oleh karena $S$. maltophilia. Namun dari berbagai studi lain, tampak bahwa bakteri ini juga dapat menyebabkan bakteremia sehingga dapat terjadi infeksi yang menyebar luas dengan mortalitas yang tinggi baik pada pasien anak maupun dewasa dengan kondisi klinis sakit yang sudah berat. ${ }^{9,17,20,21}$ Bakteremia oleh S. maltophilia dengan paru sebagai fokus infeksi memberikan prognosis yang buruk. ${ }^{22}$ Salah satu faktor lain yang meningkatkan mortalitas sesuai studi Eun Jim Kim dkk. (2019) adalah resistensi $S$. maltophilia terhadap antibiotik quinolone. ${ }^{21}$ Pada penelitian ini, didapatkan 2 
pasien yang ditemukan resistensi levofloxacin juga meninggal. Terdapat 2 pasien pada penelitian ini yang ditemukan $S$. maltophilia berulang, dan keduanya juga merupakan pasien dengan Pneumonia Covid19. Salah satu pasien dapat pulih, akan tetapi pasien lain meninggal, seperti yang dilaporkan pada penelitian lain Pek dkk. di Amerika. ${ }^{17}$ Dengan adanya pemasangan ventilator, salah satu faktor yang mungkin berperan adalah pembentukan biofilm. ${ }^{1}$

Walaupun S.maltophilia paling sering ditemukan dari spesimen saluran napas, virulensi bakteri yang rendah menyebabkan bakteri ini umumnya bukan sebagai patogen utama yang ditemukan sebagai penyebab pneumonia di suatu rumah sakit. ${ }^{12}$ Terbukti dari studi yang dilakukan Ervina dkk. (2021) di sebuah RS di Bogor, prevalensi S.maltophilia sebagai penyebab pneumonia hanya $4,05 \%$ dari 79 sampel spesimen saluran napas yang diperiksa. ${ }^{23}$ Serupa dengan penelitian pada patogen penyebab VAP di RS Harapan Kita, di mana ditemukan S.maltophilia berperan dalam 9,5\% dari 116 spesimen saluran napas bawah atau peringkat 3 di bawah bakteri lain dalam penelitian tersebut seperti Pseudomonas sp. $(22,4 \%)$ dan Pseudomonas aeruginosa $(18,1 \%){ }^{24}$ Data yang diperoleh dalam penelitian ini, S.maltophilia berperan sangat besar yaitu hingga $25,31 \%$ dari total keseluran spesimen saluran napas bawah. Beberapa faktor seperti penggunaan antibiotik yang digunakan untuk terapi, kepatuhan cuci tangan, serta penggunaan jenis desinfektan diperkirakan menjadi faktor dalam tingginya angka ini.

Penelitian ini memberi informasi bahwa kepekaan cotrimoxazole dan levofloxacin masih sangat baik (>80\%) sehingga keduanya masih bisa disarankan sebagai terapi empirik walaupun pola kepekaan cotrimoxazole sedikit lebih baik dibandingkan levofloxacin. Hasil serupa juga didapatkan pada penelitian di Amerika oleh Hamdi dkk. (2020), dengan angka kepekaan cotrimoxazole 97\%, lebih tinggi dibandingkan levofloxacin $75,5 \% .^{22}$ Didapatkan persentase kepekaan yang serupa untuk levofloxacin di Hungaria, Eropa, oleh Jihasz dkk. (2014) pada pasien yang terbukti infeksi yaitu $74 \%$, sedangkan pada kasus kolonisasi, kepekaan levofloxacin mencapai $84 \%$. Berbeda dengan cotrimoxazole di mana pada kasus infeksi dan kolonisasi, kepekaannya relatif sama yaitu 99 dan $98 \% .^{8}$ Penelitian di Korea Selatan oleh Hae-Sun Chung dkk (2012), juga menemukan bahwa kepekaan cotrimoxazole lebih tinggi yaitu mencapai $94 \%$, sedangkan levofloxacin $81 \%$. Penelitian mengenai kepekaan S. maltophilia di Asia Tenggara, seperti di Thailand oleh Isuwanno dkk. (2020), Kepekaan cotrimoxazole dan levofloxacin tidak berbeda jauh yaitu berturut-turut 94 dan $91 \% .{ }^{19}$ Berbeda dengan hasil kepekaan cotrimoxazole pada studi S.maltophilia di Mataram yang hanya mencapai $8,33 \%$, sedangkan untuk levofloxacin tidak dilakukan uji melainkan menguji terhadap fluoroquinolone lain yaitu ciprofloxacin dengan sensitivitas 58,3\%. ${ }^{16}$ Berdasarkan data ini, sensitivitas levofloxacin tidak dapat dipastikan secara mutlak namun diperkirakan tidak akan jauh dari 58,3\%. Perbedaan hasil uji kepekaan pada penelitian Hagni dkk dan hasil dari penelitian ini dapat diakibatkan dari perbedaan alat identifikasi yang digunakan. ${ }^{25}$ Penelitian Hagni dkk menggunakan metode MIC dari Phoenix, berbeda dengan penelitian ini yang menggunakan Vitek2 untuk cotrimoxazole dan cakram untuk levofloxacin. Hingga studi ini ditulis, belum ada studi lainnya yang dipublikasi mengenai pola kepekaan S. matophilia di Indonesia.

\section{Simpulan}

Stenotrophomonas maltophilia merupakan bakteri dengan resistensi intrinsik yang luas serta dapat bertahan di lingkungan sehingga eradikasi bakteri ini harus melibatkan pengendalian infeksi lingkungan di rumah sakit. Mortalitas pasien dengan infeksi $S$. maltophilia cukup tinggi, meskipun ada kemungkinan disebabkab oleh kondisi klinis pasien yang sudah memiliki penyakit lain dalam stadium lanjut. Antibiotik yang disarankan untuk digunakan dalam mengatasi infeksi akibat $S$. maltophilia seperti cotrimoxazole dan levofloxacin masih dapat digunakan karena angka sensitivitas yang didapatkan masih tinggi, namun perlu dilakukan studi yang lebih luas di Indonesia untuk mendapatkan kepekaan $S$. maltophilia terhadap antiobiotik ini.

\section{Daftar Pustaka}

1. Bennet J, Dolin R, Blaser M. Principe and practice of infectious diseases.8th ed. 2015.p2532-9.

2. Watanabe K, Zhu H, Willcox M. Susceptibility of Stenotrophomonas maltophilia clinical isolates to antibiotics and contact lens multipurpose disinfecting solutions. Investig Ophthalmol Vis Sci. 2014;55(12):8475-9.

3. Al-Anazi KA, Al-Jasser AM. Infections caused by Stenotrophomonas maltophilia in recipients of hematopoietic stem cell 
transplantation. Front Oncol. 2014;4:1-11.

4. Budayanti NS, Aisyah DN, Fatmawati NND, Tarini NMA, Kozlakidis Z, Adisasmito W. Identification and distribution of pathogens in a major tertiary hospital of Indonesia. Front Public Heal. 2020;7:1-8.

5. Nseir S, Di Pompeo C, Brisson H, Dewavrin F, Tissier S, Diarra M, et al. Intensive care unitacquired Stenotrophomonas maltophilia: Incidence, risk factors, and outcome. Crit Care. 2006;10(5):1-9.

6. Guerci P, Bellut H, Mokhtari M, Gaudefroy J, Mongardon N, Charpentier C, et al. Outcomes of Stenotrophomonas maltophilia hospitalacquired pneumonia in intensive care unit: A nationwide retrospective study. Crit Care. 2019;23(1):1-13.

7. Guyot A, Turton JF, Garner D. Outbreak of Stenotrophomonas maltophilia on an intensive care unit. J Hosp Infect. 2013;85(4):303-7.

8. Juhász E, Krizsán G, Lengyel G, Grósz G, Pongrácz J, Kristóf K. Infection and colonization by Stenotrophomonas maltophilia: Antimicrobial susceptibility and clinical background of strains isolated at a tertiary care centre in Hungary. Ann Clin Microbiol Antimicrob. 2014;13(1):1-7.

9. Jeon YD, Jeong WY, Kim MH, Jung IY, Ahn MY, Ann HW, et al. Risk factors for mortality in patients with Stenotrophomonas maltophilia bacteremia. Medicine. 2016;95(31):e4375.

10. Gideskog M, Welander J, Melhus Å. Cluster of S. maltophilia among patients with respiratory tract infections at an intensive care unit. Infect Prev Pract. 2020;2(4):100097.

11. Alsuhaibani M, Aljarbou A, Althawadi S, Alsweed A, Al-Hajjar S. Stenotrophomonas maltophilia bacteremia in children: risk factors and mortality rate. Antimicrob Resist Infect Control. 2021;10(1):1-7.

12. Brooke JS. Stenotrophomonas maltophilia: an emerging global opportunistic pathogen. Clin Microbiol Rev. 2012;25(1):2-41.

13. Gröschel MI, Meehan CJ, Barilar I, Diricks M, Gonzaga A, Steglich M,et al. The phylogenetic landscape and nosocomial spread of the multidrug-resistant opportunist Stenotrophomonas maltophilia. Nat Commun. 2020;11(1):2044.

14. CLSI. CLSI M100-ED29. Performance Standards for Antimicrobial Susceptibility Testing. 29th Edition. 2019.

15.Samonis G, Karageorgopoulos DE, Maraki S, Levis P, Dimopoulou D, Spernovasilis NA, et al. Stenotrophomonas maltophilia infections in a general hospital: Patient characteristics, antimicrobial susceptibility, and treatment outcome. PLoS One. 2012;7(5):e37375.

16. Wardoyo EH. Bakteri non fermenter sebagai patogen fokus pada spektrum infeksi Stenotrophomonas maltophilia di Kota Mataram. 2016;5(2):7-9.

17. Pek Z, Cabanilla MG, Ahmed S. Treatment refractory Stenotrophomonas maltophilia bacteraemia and pneumonia in a COVID-19positive patient. BMJ Case Rep. 2021;14(6):13.

18. Safdar A, Rolston K V. Stenotrophomonas maltophilia: changing spectrum of a serious bacterial pathogen in patients with cancer. Clin Infect Dis. 2007;45(12):1602-9.

19. Insuwanno W, Kiratisin P, Jitmuang A. Stenotrophomonas maltophilia infections: clinical characteristics and factors associated with mortality of hospitalized patients. Infect Drug Resist. 2020;13:1559-66.

20. Zhu L, Wang L, Zhang Y, Chen R, Li X, Sun $\mathrm{J}$, et al. Fatal hemorrhagic pneumonia in patients with hematologic diseases and Stenotrophomonas maltophilia bacteremia: a retrospective study. BMC Infect Dis. 2021;21(1):1-10.

21. Kim EJ, Kim YC, Ahn JY, Jeong SJ, Ku NS, Choi JY, et al. Risk factors for mortality in patients with Stenotrophomonas maltophilia bacteremia and clinical impact of quinoloneresistant strains. BMC Infect Dis. 2019;19(1):1-8.

22. Hamdi AM, Fida M, Abu Saleh OM, Beam E. Stenotrophomonas bacteremia antibiotic susceptibility and prognostic determinants: Mayo Clinic 10-year experience. Open Forum Infect Dis. 2020;7(1):1-4.

23. Theresia E, Dharmawan A, Harahap ED, TannadyTan H, Latifah R. Gambaran pola bakteri dan kepekaan antibiotik pada pasien rawat inap dengan pneumonia di Rumah Sakit Paru dr . M . Goenawan Partowidigdo. Jurnal Kedokteran Meditek. 2021;27(2):102-8.

24. Widyaningsih R, Buntaran L. Pola kuman penyebab ventilator associated pneumonia(VAP) dan sensitivitas terhadap antibiotik di RSAB Harapan Kita. Sari Pediatr. 2016;13(6):384.

25. Khan A, Arias CA, Abbott A, Bard JD, Bhatti MM, Humphries RM. Evaluation of the vitek 2, phoenix, and microscan for antimicrobial susceptibility testing of Stenotrophomonas maltophilia. J Clin Microbiol. 2021;59(9). 